\title{
Histopathological changes in the stomach wall of the European grayling Thymallus thymallus associated with severe infection by the nematode Cystidicoloides ephemeridarum
}

\author{
MAREK KULIKOWSKI, ZENON SOŁTYSIAK*, JERZY ROKICKI \\ Department of Invertebrate Zoology and Parasitology, Faculty of Biology, \\ University of Gdańsk, Wita Stwosza 59, 80-308 Gdańsk, Poland \\ *Division of Parasitology, Faculty of Veterinary Medicine, \\ Wrocław University of Environmental and Life Sciences, Norwida 31, 50-375 Wrocław, Poland
}

\section{Kulikowski M., Sołtysiak Z., Rokicki J.}

\section{Histopathological changes in the stomach wall of the European grayling Thymallus thymallus associated with severe infection by the nematode Cystidicoloides ephemeridarum}

\section{Summary}

This study is a report of lesions associated with the nematode Cystidicoloides ephemeridarum (Linstow, 1972). It is a common parasite of the stomach mucosa of fish, mainly salmonids. In stomachs of 30 graylings were observed strong infection with C. ephemeridarum caught in July 2013 and February 2014 in the Dobrzyca River were examined. Adult nematodes, including females with mature eggs, and L3 and L4 larvae were recorded. Stomachs of graylings with intensive infection (146-261examples) were examined. The histological examination of a sample taken from the tissue surrounding nematodes revealed the presence of more or less confluent focal areas of destruction of gastric laminae. The numerous invasions of $\mathrm{C}$. ephemeridarum are associated with intensive feeding of fish, but the different developmental stages of the parasite do not induce sufficiently strong histopathological changes in the stomach of graylings to be a cause of their death.

Keywords: histopathology, Cystidicoloides ephemeridarum, grayling, Thymallus thymallus

The European grayling Thymallus thymallus (Linnaeus, 1785) is a fish in the Salmonidae family, the Thymallinae subfamily. It occurs in Europe, mainly in fast-flowing mountainous rivers in water with a high content of oxygen. It grows up to $60 \mathrm{~cm}$ in length and $6.7 \mathrm{~kg}$ in weight. In Poland, graylings occur mostly naturally and are of economic importance due to fishing tourism. The nematode Cystidicoloides ephemeridarum has been described under two names: C. ephemeridarum (Linstow, 1872), e.g. $(3,8,14)$, and the synonym Cystidicoloides tenuissima (Zeder, $1800)$, e.g. $(1,2,15,16)$. Among nematodes observed in the grayling, these two species have never been noted together. Accordingly, it can be assumed that the grayling parasites described as $C$. tenuissima belong to the same species as the ones found by us in the fish stomachs examined. Barskaya and Novokhatskaya (2), and Dorovskikh (5) consider the European grayling to be the most important definitive host of $C$. ephemeridarum, whilst Moravec (15) concluded that, on the contrary, the grayling is not the main definitive host of this nematode. There are relatively few reported cases of histopathological lesions of the stomach wall of fish $(4,13)$. The nematode $C$. ephemeridarum is a common parasite, particularly of salmonids in the Holarctic. Both larvae stage and adults are present in the stomach and sometimes occur in large quantities. C. ephemeridarum was recorded in the grayling stomachs $(6,8,10,15,17$, 18). There is no description, in the available literature, of histopathological changes in the stomach wall of the European grayling as a result of the presence of the $C$. ephemeridarum. The purpose of this work was to determine the influence of larval and adult stages of C. ephemeridarum on the stomach wall of the grayling.

\section{Material and methods}

Grayling (L 300-342 mm) from the Dobrzyca River nearby Wałcz, northern Poland, were caught with a fly fishing rod. Two samples were taken: on 7 July 2013 near Ostrowiec $(\mathrm{n}=15$ fish) and on 12 February 2014 near Pluskot $(\mathrm{n}=15)$. 
Stomach samples with nematodes $C$. ephemeridarum were collected for histopathological examination.

All samples were fixed in 10\% buffered formalin, dehydrated in graded alcohol and xylene and embedded in paraffin, $6 \mu \mathrm{m}$ thick sections, which were stained with hematoxylin and eosin (H\&E). Nematodes recovered from the stomach for morphological identification were fixed in $70 \%$ ethanol with $5 \%$ glycerol, cleared by evaporation of the ethanol/glycerin mixture and examined with a light microscope.

\section{Results and discussion}

Adult and L3 and L4 stage larvae of the nematode C. ephemeridarum were found in the mucosa and lumen of the grayling stomachs (Tab. 1 and Tab. 2). Differences in infection parameters between the summer (July) and the winter (February) were observed. In the summer, the average intensity, the scope of intensity, and the density of parasites were much higher, while the extensity was a little lower. In general, regardless of the season, twice as many L3 and L4 larvae as adults were observed (Tab. 2).

Light microscopic micrographs of a longitudinally sectioned (paraffin section) anterior body of C. ephemeridarum attached to the gastric wall of the fish were taken. Not one, but three or more parasites were often observed at the site of attachment.

The histopathological examination tissue samples taken from the gastric wall of fish at the places where the parasites were attached causes usually focal atrophy of gastric laminae mucosae or destruction but inflammatory reaction with cell infiltration was not observed.

At the center of the areas, single or multiple parasitic elements of irregular shape, with a thick segmented cuticle covering the dorsal and ventral musculature and the lateral, dorsal and ventral chords were observed (Fig. 1). Inside the pseudocoel, elements resembling gastroenteric-like structures, eggs with forming larvae and the lateral chords of the parasite were detected (Fig. 2a, b). The worms did not provoke a surrounding inflammatory reaction, but stomach laminae at the site of attachment was damaged and absent and was radically
Tab. 2. Percentage composition of various development stages of nematodes $C$. ephemeridarum observed in the stomachs of the graylings from the Dobrzyca River

\begin{tabular}{|l|c|c|c|}
\hline \multicolumn{1}{|c|}{ Data } & \multicolumn{3}{|c|}{ Infection [\%] } \\
& + & 0 & L3, L4 \\
\hline 2013.07.07 & 18.8 & 16.7 & 64.5 \\
2014.02.12 & 16.0 & 15.0 & 69.0 \\
Total & 18.4 & 16.4 & 65.2 \\
\hline
\end{tabular}

shorter than normal epithelium covered the laminae and gastric glands near the attachment of parasites that was damaged. The gastric muscle was normal.

The growth and development of larvae L3 to L4 and adult take place at the stomach of grayling. The presence of larval stages in summer $(64.5 \%)$ and winter $(69.0 \%)$ (Tab. 2) provides a high level of infection in both seasons in the Dobrzyca River. Moravec (15), studying C. ephemeridarum from the Bystrice River in the Czech Republic, noticed a seasonal rhythm and found the eggs-producing female nematodes are present only from May until July, and from September until October. The mean intensity followed the typical seasonal trend for this parasite in salmonids from the Northern Hemisphere were presented by Greenwood and Baker (9). Seasonal rhythm is largely due to a seasonal occurrence of the intermediate hosts and to the water temperature, although the effects of other factors cannot be excluded (15). Moravec (15) examined 7 graylings from the Bystrice River in May, June, July, August and December, these nematodes were found in only two of them, the intensity of infection being very low. In contrast to the Dobrzyca River, in the Bystrice

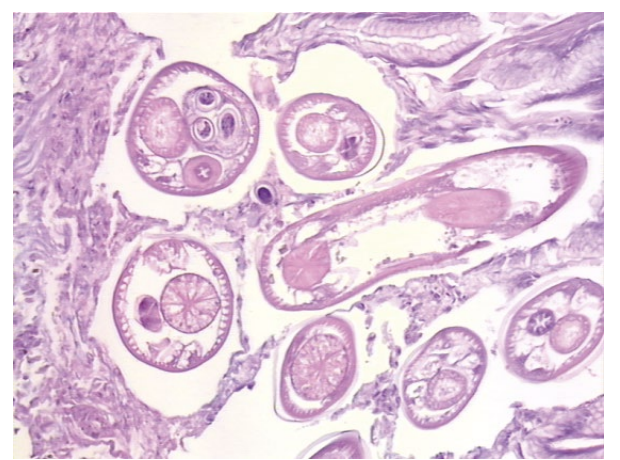

Fig. 1. Single or multiple transverse and irregular shape of parasite elements $C y s$ tidicoloides ephemeridarum without inflammatory reaction in the stomach wall of Thymallus thymallus (H-E, mag. 100)
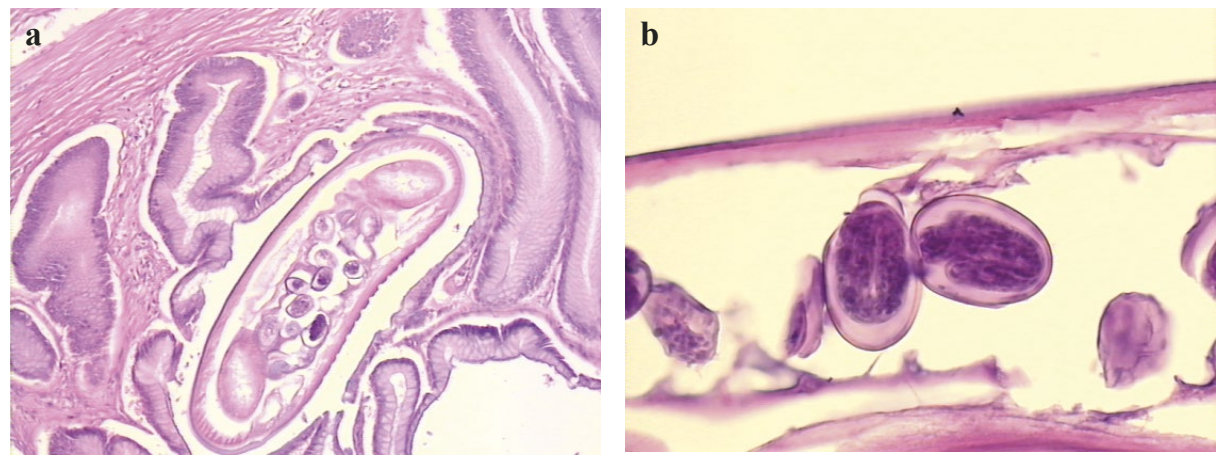

Fig. 2 (a, b). Single, irregular shape of parasite Cystidicoloides ephemeridarum in the stomach wall of Thymallus thymallus. Inside the irregular shape of the parasite eggs with forming larvae are visible (H-E, mag. 100, 400) 
River the main definite host of C. ephemeridarum is not the grayling but brown trout ( $S$. trutta $m$. fario). The infection parameters of the examined fish by nematodes C. ephemeridarum are rather high (mean intensity 128 , range 10-842 examples) as compared to the observations of others studying the European grayling, respectively e.g.: Fagerholm et al. (8), 8.8, Kulikowski and Rokicki (10), 12, 1-146, Rumyantsev (16), 1-895, and Wierzbicki (18) $1.8,1-150$.

Despite the high nematode infestation of fish the presence of visible changes in the stomach wall is not noted as such by the histological studies. Our study showed that strong infection of the nematodes Cystidicoloides ephemeridarum did not provoke a surrounding inflammatory reaction. There is a clear reaction by the cell wall of the stomach to the majority of nematode infestation. The relatively few described cases of histopathological lesions of the stomach of fish are varied. Acanthocheilus nidifex in the stomach of Galeocerdo cuvieri fish cause inflammation, the formation of connective tissue and vascularization (13). Nematodes such as Goezia are pathogenic to the fish gastrointestinal tract. Goezia pelagia in the stomach of fish Rachycentron canadum induces nodules, lesions, haemorrhage, slight autolysis of gastric glands (4). In the opinion of Moravec (15) the pathology of $C$. ephemeridarum has not hitherto been elucidated. Apparently the nematodes cause damage to the mucosa of the stomach and, in their frequent mass occurrence, they debilitate the fish host. In the present work histopathological changes related mainly to presence of more or less confluent focal areas of destruction gastric lamina at the site of attachment of nematodes.

The histopathology of Cystidicoloides ephemeridarum were studied in speckled trout, Salvelinus fontinalis, from the Rocky Saugeen River, Ontario, Canada. Infrequently, superficial disruptions of the mucosal epithelium occurred adjacent to worms located close to the stomach lining, but underlying tissues appeared unaffected (9). It is not known whether the response is a parasite cell specific or non-specific reaction and that the extension of the pathology is associated with primary infection, reinfection or other causes. As can be seen in previous work, the strong dynamics of infection by $C$. ephemeridarum deals with reinfection (10). The gastric muscle was normal but epithelium covered the laminae and the gastric glands near the attachment of parasites were damaged. This would possibly corroborate the observations that monogeneans move frequently before they establish a more permanent attachment spot, allowing the pits to close rapidly because of the relatively shallow depth of penetration during their brief attachment (12).

In general, regardless of the season, twice as many L3 and L4 larvae as adults were observed (Tab. 2). Łopieńska-Biernat et al. (11) suggest the metabolic differences were confirmed by the data of protein analysis in extract of L3 and L4 Anisakis simplex. The total protein pool showed both quantitative and qualitative differences reflected in the presence of five stage-specific frac- tions in extracts from larval stages. Some of the enzymes can be responsible for penetration of nematodes. The level of enzyme penetration of the nematode larvae will have an impact on the ability of damaging the tissues of the host. The level of activity of the excretory-secretory products of both adult nematodes and L3 and L4 larvae which contain a number of hydrolase enzymes that can damage host tissue (7) suggest that it is Contracaecum rudolphii that secretes enzymes and not the mouth apparatus that participates in tissue damage.

The size of histological changes of the host stomach is associated with a host-parasite arrangement. The low level of pathogenicity of C. ephemeridarum exhibited in graylings was perhaps indicative of a good hostparasite relationship. The work shows rarely featured relatively small histological changes in the stomach wall of graylings in spite of strong parasitic infestations of the nematodes Cystidicoloides ephemeridarum.

\section{References}

1. Aho J. M., Kennedy C. R.: Seasonal population dynamics of the nematode Cystidicoloides tenuissima (Zeder) from the River Swincombe, England. J. Fish Biol. 1984, 25, 473-489.

2. Barskaya Yu., Novokhatskaya O.: Distribution of nematode Cystidicoloides tenuissima in the fish biocenoses of Paanajarvi-Olanga lake-river system. Fifth Internat. Nematology Symposium, Vladivostok 2003

3. Barskaya Yu. Yu, Ieshko E. P., Lebedeva D. I.: Parasites of Salmonidae fish of Fennoscandia. Practical guide. Petrozavodsk: KarRC RAS 2008.

4. Deardorff T. L., Overstreet R. M.: Review of Hysterothylacium and Iheringascaris (both previously $=$ Thynnascaris) (Nematoda: Anisakidae) from the Northern Gulf of Mexico. Proc. Biol. Soc. Wash. 1980, 93, 1035-1079.

5. Dorovskikh G. N.: Cystidicoloides tenuissima (Nematoda: Ascarophididae) in host population of the Mezen River basin, Parazitologiia 1996, 30, 357-363.

6. Dorovskikh G. N., Stepanov V. G., Vostrikova A. V.: Component communities of parasites in the grayling Thymallus thymallus (L.) (Salmoniformes, Thymallidae) and the minnow Phoxinus phoxinus (L.) (Cypriniformes, Cyprinidae) from the Pechora river, Parazitologiia 2007, 41, 381-391.

7. Dziekońska-Rynko J., Rokicki J.: Activity of selected hydrolases in excretionsecretion products and extracts of adult Contacaecum rudolphii. Wiad. Parazytol. 2005, 51, 227-231.

8. Fagerholm H. P., Kuusela K., Valtonen E. T:: On the occurrence of Cystidicoloides ephemeridarum (Nematoda: Spiruroidea) in the stomach of grayling (Thymallus thymallus) in the Oulanka and Kitkajoki rivers (Kuusamo, Finland), Memo. Soc. Fauna Flora Fenn. 1982, 58, 67-70.

9. Greenwood S. J., Baker M. R.: Cystidicoloides ephemeridarum (Linstow, 1872) (Nematoda) in speckled trout, Salvelinus fontinalis, from southern Ontario, Can J. Zool. 1987, 65, 2589-2593.

10. Kulikowski M., Rokicki J.: Parasites of grayling Thymallus thymallus dwelling in the Pomerania rivers: Łeba, Reda and Radunia, Wiad. Parazytol. 1998, 44, 73-85.

11. Łopieńska-Biernat E., Żółtowska K., Rokicki J.: Glycogen catabolism enzymes and protein fractions in the third and fourth larval stages of Anisakis simplex, J. Helminthol. 2008, 82, 45-51.

12. Madanire-Moyoa G., Avenant-Oldewage A.: The histopathology of Enterogyrus coronatus Pariselle, Lambert \& Euzet, 1991 (Monogenoidea) in the stomach of the southern mouthbrooder Pseudocrenilabrus philander (Weber, 1897) (Cichlidae), Afr. Zool. 2015, 50, 175-180.

13. Margolis L.: Nematode diseases of marine fishes, [in:] Snieszko S. F. (ed.): A Symposium on Diseases of Fishes and Shellfishes. Special Publication nr. 5, Am. Fish. Soc. 1970, 190-208.

14. Moravec F.: Metazoan parasites of salmonid fishes of Europe. Academia, Praha 2004.

15. Moravec F.: On the life history of the nematode Cystidicoloides tenuissima (Zeder, 1800) in the river Bistrice, Czechoslovakia, Folia Parasitol. 1971, 18, $107-112$

16. Rumyantsev E. A.: Parazity ryb w ozerah Evropejskogo Cevera (fauna, ekologiya, evoluciya). Petrozavodsk. PetrGU, 2007.

17. Rumyantsev E. A., Ieshko E. P., Schulman B. S.: Parasite fauna formation in the European grayling Thymallus thymallus. Parazitologiia 1999, 33, 136-143.

18. Wierzbicki K.: Prẻsence du nẻmatode Sterliadochona tenuissima (Zeder, 1800) dans le nord de la Pologne, Ann. Parasit. Hum. Comp. 1962, 3, 314-323.

Corresponding author: mgr Marek Kulikowski, ul. Wita Stwosza 59, 80-308 Gdańsk, Poland; e-mail: marek.kulikowski@biol.ug.edu.pl 